\title{
Generational Type and Employee Theft: A Case Study of Kopala Mine, Zambia
}

\author{
Adamson Mukhalipi \\ Zambia Institute of Human Resource Management, Lusaka, Zambia \\ Email: adamsonmukhalipi@ymail.com
}

How to cite this paper: Mukhalipi, A. (2021) Generational Type and Employee Theft: A Case Study of Kopala Mine, Zambia. Open Access Library Journal, 8: e7020.

https://doi.org/10.4236/oalib.1107020

Received: July 14, 2021

Accepted: August 24, 2021

Published: August 27, 2021

Copyright $\odot 2021$ by author(s) and Open Access Library Inc.

This work is licensed under the Creative Commons Attribution International License (CC BY 4.0).

http://creativecommons.org/licenses/by/4.0/ (c) (i) Open Access

\begin{abstract}
Purpose: The purpose of this study was to assess the influence of Generational Type on Employee Theft at Kopala Mine, Zambia. Method: The data set in this study is derived from the Kopala Mine Reports for 2020: HR Admin Report, Disciplinary Report on Theft and other related offences. Frequency Tables and Cross tabulations were used to summarize the findings. Findings: The study found that $56.8 \%$ of Millennials and $40.5 \%$ of Generation Xers employees were engaged in theft and other related offences. The practical research significance is that Generational Type influences Employee Theft in the organization. Conclusion: Based on the findings above, the study concludes that Generational Type and the lifestyle employees lead and influence employee theft in workplace organizations. The study further suggests that the need for extra money to meet social needs (lifestyle) is the main reason some employees engage in employee theft.
\end{abstract}

\section{Subject Areas}

Human Resource Management

\section{Keywords}

Generational Type, Theft, Engagement, Lifestyle

\section{Introduction}

The survival of corporate industries depends on maximizing profits from the existing capabilities, while recognizing and adjusting to the fact that what may work today, may not necessarily work in the future (Kortmann, Gelhard, Zimmermann, \& Piller, 2014 in Osborne and Hammond, 2017) [1]. Therefore, leaders need to understand how critical managing the balance between employee relations, adopting innovation, and maximizing short-term profits is, if they were 
to ensure a viable future for their corporations (Hill \& Birkinshaw, 2012) [2]. Musgrove et al. (2014) [3] and Mukhalipi (2018) [4] note that employee' efforts and engagement were determinants of organizational productivity. Interpersonal behaviors affect productivity; consequently, organizational leaders were monitoring how different interpersonal behaviors influence productivity (Hausknecht \& Holwerda, 2013) [5]. Bersin (2014) [6] points out that negative interpersonal behaviors could result in negative productivity due to lower employee engagement. Bersin (2014) [6] found that only $13 \%$ of worldwide employees are fully engaged at work. In addition, twice as many are so disengaged that this negative behavior is spread to other employees. Conlow (2017) [7] observes that nearly all companies were struggling in trying to improve employee engagement. As a result, $87 \%$ of the world's employees were disengaged. This costs the US economy $1 \%$ of the $\$ 20$ trillion dollar economy, that's at least 500 billion dollars. This isn't counting partially disengaged employees. The disengaged-employees were unhappy at work, absented themselves and exhibited negative behavior towards supervisors, co-workers and customers.

Similarly, a study by BlessingWhite called "The State of Employee Engagement" found that Millennials were the least engaged of all age groups as only $20 \%$ were highly engaged, compared with $26 \%$ for Generation Xers, $33 \%$ for late baby boomers, and $32 \%$ for early baby boomers. And they are the most disengaged group: $25 \%$ are disengaged, compared to $20 \%$ for Generation Xers, $17 \%$ for late baby boomers, and $18 \%$ for early baby boomers (Robertson-Smith and Markwick, 2009) [8].

However, in the history of the most global organizations including the Zambian Mining Industries, it is for the first time that four distinct generations have worked side by side: Baby Boomers (1946-1964), Generations Xers (1965-1980), Millennials (1981-2000) and Generational Type2020 (2001- or later). It is important to note that each Generational Type perceives the world differently, works differently since they have different needs. Clark (2012) argues that the Generational Type one belongs to, shapes how he or she views work and professional life. For instance, some view work as a calling, others as a career, while the Millennials view work as a gig. These four generations, though they work side by side, they all work and are shaped differently (Clark, 2012) [9]. Mukhalipi (2018) [4] observes that engaged-employees work with passion and feel a profound connection to their organization. These employees drive innovation and move the organization forward. However, in a study (John et al., 2019) [10] conducted which was aimed at assessing whether employee dissatisfaction was the root cause of workplace theft in the retail industry, on selected supermarkets in Port Harcourt, notes the alarming level that employee theft in organizations has reached and how difficult it is proving to curb as a result of dissatisfaction in the workplace.

Therefore, the purpose of this study was to assess the influence of Generational Type has on Employee Theft. The following research questions were used to guide this research: 1) What are the Generational Types prevailing in workplace 
organizations and does Generational Type influence Employee Theft? 2) What existing theories support this study? 3) Does Generational Type lead to employee theft? 4) What are the reasons for employee theft?

\section{Literature Review}

Clark (2012) [9] states that to shape professional goals, work and work life, employees need to identify the concept of career that fits them. He points out the different ways of looking at organizational life and what it means to each personality. He observes that two to three generations ago, career model was based on traditional career model (see Figure 1).

Clark (2012) [9] describes the above Model as having three stages and explains that every employee moves through three stages during lifetime. In Stage 1 or "Learn", employees get education and training so that they learn the skill in order to be employed and make a living. In Stage 2 or "Earn", Individuals get jobs and earn some money. Finally, in Stage 3 or "Burn", some day employees would retire from the job and settle into retirement and burn the resources and savings they had built up over the years.

However, Clark (2012) [9] argues that there is no amusement drawn from this Model as it portrays organizational life as a smooth, linear path with clear and distinct stages and as such, most people consider this model as simply obsolete. He therefore explains that most people find organizational life adventurous, which is filled with changes, surprises, obstacles and opportunities. It is no wonder that the average job cycle was growing shorter and the traditional long job was giving way to a career that was fraught with change and quick turns to the point that the new Generation has been referred to as general flux. $\mathrm{He}$ however, notes that an employee's concept of career today may not be the same as the concept of career tomorrow as the Generation and the context around the individual influence this. Clark (2012) [9] argues that concept of career might differ from a member of the Gen Y generation, also known as the Millennial Generation and that of a member of the baby-boom Generation as per Table 1.

Eisner (2005) observes that as the average age of the U.S. workforce continues to increase, much attention has focused on the fact that the workforce is largely comprised of three generations (i.e., Baby Boomers, Generation Xers, and Millennials; Eisner, 2005) [11]. The popular press frequently stresses the need for organizations to recruit, reward, and manage these employees differently

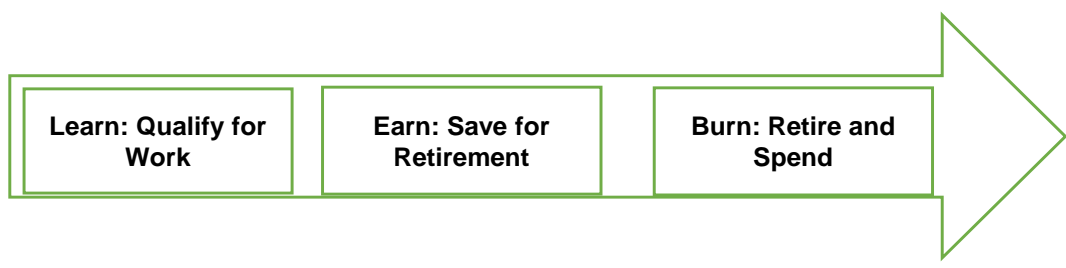

Figure 1. The traditional career model. 


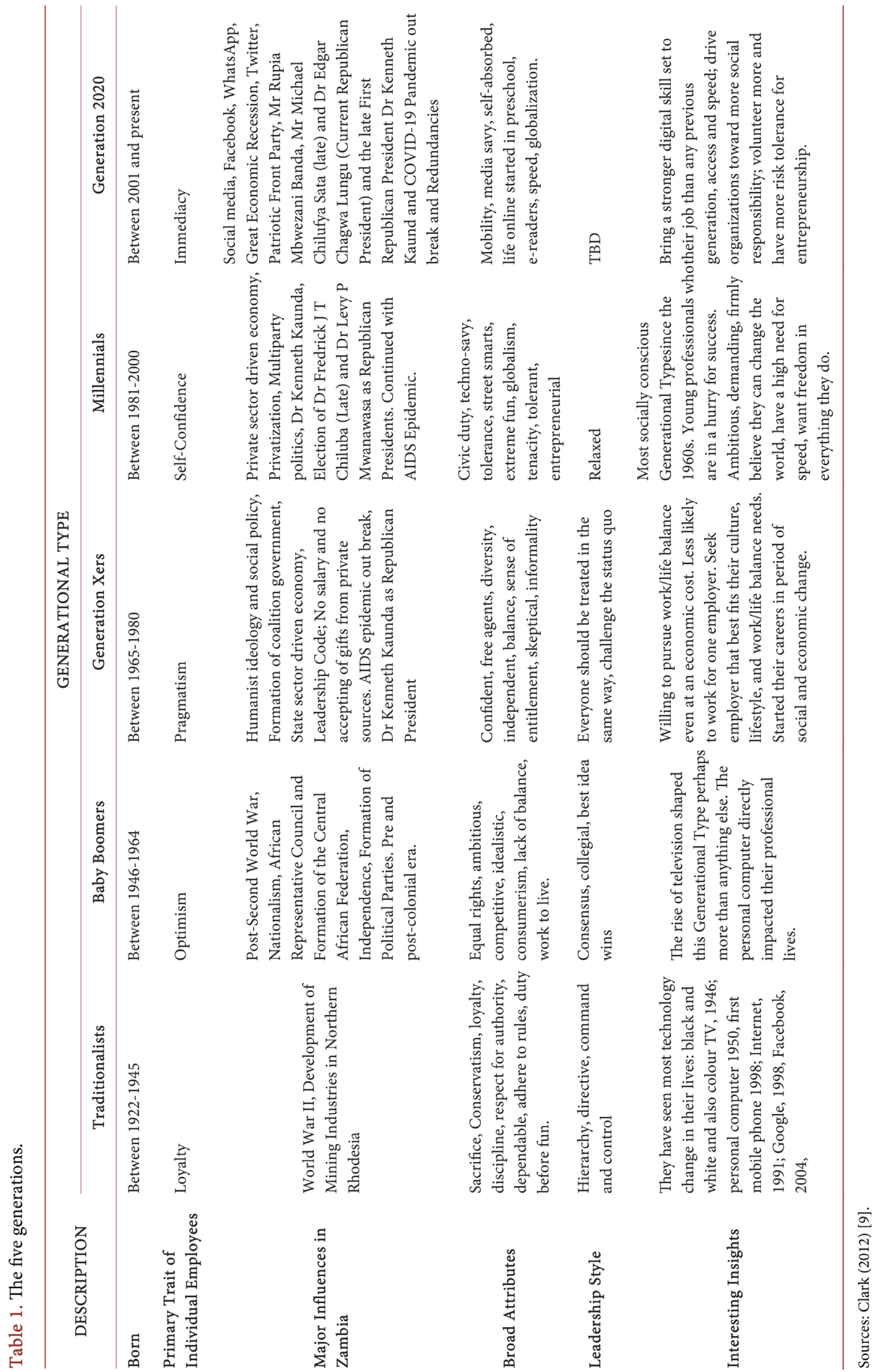


because of Generation differences in attitudes, values, and desires (Jurkiewicz \& Brown, 1998 [12]; Kupperschmidt, 2000 [13]; Macky, Gardner, \& Forsyth, 2008 [14]). Many have suggested that failure to recognize these differences could lead to negative organizational outcomes such as intergeneration workplace conflict, misunderstanding and miscommunication, poor working relationships, reduced employee productivity, poor employee well-being, lower innovation, and fewer organizational citizenship behaviors (Adams, 2000 [15]; Bradford, 1993 [16]; Dittman, 2005 [17]; Fyock, 1990 [18]; Jurkiewicz, 2000 [19]; Kupperschmidt, 2000 [13]; Smola \& Sutton, 2002 [20]; Westerman \& Yamamura, 2007 [21]; Yu \& Miller, 2003 [22]). As a result, human resource (HR) management specialists, managers, and researchers have expressed interest in identifying ways to manage and work with people from different generations (Cennamo \& Gardner, 2008) [23].

However, this is the first time in the history of the Zambian Mining Industry that four distict generations have worked side by side: Baby Boomers (1946-1964), Generations Xers (1965-1980), Millennials (1981-2000) and Generation 2020 (2001- or later). It is important to note that each Generation perceives the world differently, works differently, and has different needs. Clark (2012) [9] posit that the Generation one belongs to, shapes work and professional life. For instance, some view work as a calling, others as a career, while the Millennials view work as a gig. Although these four Generation work side by side, they all work and shape different. A study by Blessing White (2008) on "The State of Employee Engagement" [24] found that Millennials were the least engaged of all age groups as only $20 \%$ were highly engaged, compared with $26 \%$ for Generation Xers, $33 \%$ for late baby boomers, and $32 \%$ for early baby boomers. And they are the most disengaged group: $25 \%$ are disengaged, compared to $20 \%$ for Generation Xers, $17 \%$ for late baby boomers, and $18 \%$ for early baby boomers (Robertson-Smith and Markwick, 2009) [10].

\section{Engaged or Disengaged: What Demotivates Employees?}

Byrne (2014) points out that different drivers of engagement among different generations may result into their engagement or disengagement in the workplace. However, (Byrne, 2014) calls on scholars to pay very close attention to disengagement and the components that inhibit or deter employee engagement (Byrne, 2014) [25].

Disengagement refers to people who withdraw themselves and display effortless performance (Byrne, 2014) [25]. Disengaged employees usually remove themselves from challenging or questioning others (conflict) and simply do as they are told (Byrne, 2014) [25]. Millennials often appear as disengaged employees because they are seen as self-centred and often exemplify a "what's in it for me attitude" (Deal et al., 2010) [26]. Conversely, the perception of Baby Boomers is positive, as they are considered highly engaged and hard workers climbing the corporate ladder for higher positions (Wong et al., 2008) [27].

The few salient reasons contributing to employee disengagement are work bur- 
nout, personal situations, and emotional exhaustion. Burnout occurs when employees distance themselves emotionally and cognitively. Personal situations occur when life or work is unbalanced. Emotional exhaustion involves employees' health and well-being. Relative to these drivers, scholars propose that there are further inhibitors to engagement, such as distrust, inequality, organizational change, staff reduction and loss of job resources, threats to psychological availability, meaningfulness, and safety (Byrne, 2014 and Mukhalipi, 2018 [4]). Beyond these deterrent drivers or inhibitors, there are common problems found amongst employees: conflicts or hostilities between others, withdrawn interactions, miscommunication or aggressive communication, and lack of interest (Dyer, 1995) [28]. These common problems stem from differences in values, ambitions, views, mind-sets, demographics, and intergeneration conflict (Zemke et al., 1999) [29].

\section{Theoretical Framework}

This section covers the following theories; Generation Cohort Theory, Engagement Theory Self-Determination Theory and Crime Theories; Routine Activity Theory, Crime Pattern Theory, The Rational Choice Perspective.

\subsection{Generation Cohort Theory}

The concept of generations and their effects have long been discussed by researchers in anthropology, sociology, and social psychology (Hung, Gu, \& Yim, 2007) [30]. Kupperschmidt (2000) [13] and Mannheim (1972) [31] described a Generation or a cohort as consisting people of similar age in a similar location who experience similar social, historical, life events and shared experiences such as; industrialization, fundamental changes, cataclysmic events, and tragedies which differentiate one Generation from another (Jurkiewicz \& Brown, 1998) [12]. These shared experiences have a profound effect on the values, attitudes, expectations of Generation groups and their beliefs, (Abramson \& Inglehart, 1995 [32]; Inglehart, 1977 [33]; Inglehart \& Norris, 2003 [34]). Rogler (2002) [35] proposed that the formation of a generation's collective identity occurs in the following ways.

- First, significant events such as disasters, wars, or revolutions challenge the existing social order and lay the foundation for the emergence of a new generation.

- Second, these events have a stronger effect on the "coming-of-age" group than on other age groups coexisting during the same period of time because people tend to form value systems during the pr-eadult years whereas the values of older generations are already solidified (McCrae et al., 2002) [36].

- Third, this shared set of values and goals is supported by peers in the same Generation and persists throughout adulthood (Kupperschmidt, 2000 [13]; Macky et al., 2008 [14]).

\subsection{Engagement Theory, Self-Determination Theory}

Deci and Ryan (1985) [37] note that the Self-Determination Theory (SDT) 
which has been used in professional and academic research, relates to employee engagement. SDT relates to natural or intrinsic tendencies to behave in healthy and effective ways. Employee engagement and human behaviors have a connection to the SDT and the essence of work engagement (Deci \& Ryan, 1985) [37]. An employee's level of engagement derives from his or her being able to control personal behaviors and goals.

Disengagement and personal engagement are related to the SDT in that an employee's behavioral state is a key driver of motivation to demonstrating behavior at the professional and personal levels. The engagement level of employees affects the productivity of an organization (Mukhalipi, 2018) [4], job satisfaction and the emotional state of an employee also relates to motivation (Deci \& Ryan, 1985) [37]. When employees begin to withdraw, and hide their identities, ideas, and feelings, they become disengaged and defensive, resulting in an adverse effect on work performance (Deci \& Ryan, 1985) [37].

Employee engagement strategies implemented by business leaders result in higher levels of employee engagement (Blattner \& Walter, 2015) [38], customer satisfaction, productivity, and profit (Bowen, 2016 [39] and Mukhalipi, 2018 [4]), and lower levels of employee accidents and turnovers (Barrick, Thurgood, Smith, \& Courtright, 2014) [40]. Business leaders adopt the concept of SDT to enable employees to hold positive attitudes toward their organization (Mowbray, Wilkinson, \& Tse, 2014) [41].

\subsection{Crime Theories}

\subsubsection{The Routine Activity Theory}

The Routine Activity Theory explains the dynamics of criminal events, patterns in criminal victimization, and predictions of victimization risks/likelihood (Tewksbury et al., 2014) [42]. The theory hypothesizes three necessary locational elements that must be present for crime to occur:

1) Presence of potential offenders (individuals seeking or willing to commit offenses).

2) Presence of suitable targets (individuals or property that is vulnerable or available).

3) An absence of capable and willing guardians (a lack of protection/supervision to ward off an offender).

The theory is based on two central propositions: First, lifestyles or routine activities create criminal opportunity structures by increasing the frequency and intensity of contacts between potential offenders and suitable targets. Second, potential offenders likely assess the perceived value of a target as well as whether there are any available forms of guardianship (or lack thereof) present when considering when, where, and upon whom to commit their crimes.

\subsubsection{Crime Pattern Theory}

Crime pattern theory provides a framework of environmental characteristics, offender perceptions, and offender movements to explain the spatially patterned 
nature of crime. It is compatible with routine activities theory because it describes the process by which offenders search for or come across suitable targets. P. J. Brantingham and Brantingham (1981) [43] posit that individuals are motivated to commit crime whenever they engage in their target selection process, the environment emits cues that indicate the cultural, legal, economic, political, temporal, and spatial characteristics/features of the area. The individual then uses these elements to interpret the area as being either favorable or unfavorable for crime. Over time, offenders form templates of these cues on which they rely to interpret the environment during target selection. P. J. Brantingham and Brantingham (1993) [44] explains that one common way offenders encounter their targets is through overlapping or shared activity spaces; in other words, offenders come across their targets during the course of their own routine activities, and therefore the locations of these activities and the routes travelled determine the patterning of crime across space. Brantingham and Brantingham (1993) [44], referred to the offender's home, work, school, and places of recreation as nodes. The routes travelled between these nodes were referred to as the paths of the offender. Edges are those physical and mental barriers along the locations of where people live, work, or play.

The offender is most likely to search for and/or encounter targets at the nodes, along paths, and at the edges, with the exception of a buffer zone around each node that the offender avoids out of fear of being recognized. Clustering of crime events along major nodes and paths of activity, as well as constrained by edges of landscapes. Therefore, spatial patterns of crime tend to reflect the environmental backcloth and the heavily patterned activity paths, nodes, and edges. Some places have particularly high levels of crime because of the characteristics of the activity and people associated with it whereas, some other areas were crime generators, in that people travel to these locations for reasons other than crime, but the routine activities at these places provide criminal opportunities. Conversely, other places are crime attractors in that their characteristics draw offenders there for committing crimes (Brantingham and Brantingham, 1993) [44].

\subsubsection{The Rational Choice Perspective}

The rational choice perspective addresses the processes by which offenders make decisions. Clarke and Cornish (1985) [45] explains that the decision to offend actually comprises two important decision points:

1) An involvement decision: The involvement decision refers to an individual's recognition of his or her readiness to commit a crime (Clarke \& Cornish, 1985) [45]. The offender has contemplated this form of crime and other potential options for meeting his or her needs and concluded that he or she would commit this type of crime under certain circumstances. The individual's prior learning and experiences influences this process.

2) An event decision: This decision is highly influenced by situational factors though people do not perceive situations the same way but each person views 
them through based on previous experience and assesses them using his or her information-processing abilities (Clarke \& Cornish, 1985) [45]. At times, the information used to make decisions is inaccurate, with judgment being clouded by situational changes, drugs, and/or alcohol.

Although this model describes involvement and event decisions as two discrete choices, in reality the two may happen almost simultaneously. Clarke and Cornish (1985) [45], point out that over time, experience shapes the involvement decision. Positive reinforcement from any criminal events could lead to increased frequency of offending. The individual's personal circumstances might change to further reflect his or readiness to commit crime. For example, Clarke and Cornish (1985) [45] note that increased professionalism in offending, changes in lifestyle, and changes in network of peers and associates as personal conditions that change over time to solidify one's continual involvement decision. Conversely, an offender may choose to desist in response to re-evaluating alternatives to crime. This decision could be influenced by an aversive experience during a criminal event, a change to one's personal circumstances, or changes in the larger opportunity context (Clarke \& Cornish, 1985) [45]. Both the involvement and event decisions could be viewed as rational in that they are shaped by the effort, risks, rewards, and excuses associated with the behavior.

\subsubsection{Opportunity Theory}

This opportunity theory suggests that people are inherently greedy and that every employee would steal if given the chance (Astor, 1972 [46]; Lipman, 1978 [47]). Opportunity certainly correlates positively with theft (Kantor, 1983 [48]; Lydon, 1984 [49]).

\subsection{Factors Leading to Employee Theft Incidents}

Neihoff and Paul (2000) [50] attribute employee theft to employee personality characteristics, social environment and flaws in the organization's control system. Similarly, (John et al., 2019) [10] attribute employee theft to individual character, attitude, financial needs and others due to opportunity and job dissafiaction (Kulas et al. (2006) [51] in form of pay inequity (Moorthy et al., 2011) [52] work environment, inadequate reward and level of cognitive moral development. Personal attitudes and perceptions of individual workers are also some of the main reasons for employee theft (McClurg \& Butler 2006) [53].

However, Krippel (2008) [54] believes that social inequity, criminal background, corporate wages, greed, managerial misconduct, life-style, organizational structure and climate amongst others cause employee theft. Krippel (2008) [54] believes that inadequate reward for performance stands tall amongst the various causes of theft and brings about deep feelings of dissatisfaction among employees.

\section{Data Source}

The data set in this study derived from the MCM Reports for 2020 [55]: HR 
Admin Report, Disciplinary Report on Theft and other related Offences. Frequency Tables and Cross tabulations were used to summary the findings.

\section{Findings}

Table 2. Generational type.

\begin{tabular}{ccc}
\hline & Frequency & Percent \\
\hline Millennials (1981-1996) & 21 & $56.8 \%$ \\
Generation Xers (1965-1980) & 15 & $40.5 \%$ \\
Baby Boomers (1946-1964) & 1 & $2.7 \%$ \\
TOTAL & 37 & $100 \%$ \\
\hline
\end{tabular}

\section{Comment}

Table 2 shows that $56.8 \%$ of Millennials and $40.5 \%$ of Generation Xers employees were disciplined for theft and other related offences between Jan and October 2020. The practical research significance is that Generational Type influences Employee Theft in the organization.

Table 3. Cross tabulation on generational type and years of service.

\begin{tabular}{|c|c|c|c|c|}
\hline & \multicolumn{3}{|c|}{ Service } & \multirow{2}{*}{ TOTAL } \\
\hline & Below 10 yrs & $11-20 \mathrm{yrs}$ & $21-30 \mathrm{yrs}$ & \\
\hline Millennials (1981-1996) & $13(35.1 \%)$ & $7(18.9 \%)$ & $1(2.7 \%)$ & $21(56.8 \%)$ \\
\hline Generation Xers (1965-1980) & $11(29.7 \%)$ & $4(10.8 \%)$ & $0(0 \%)$ & $15(40.5 \%)$ \\
\hline Baby Boomers (1946-1964) & $1(2.7 \%)$ & $0(0 \%)$ & $0(0 \%)$ & $1(2.7 \%)$ \\
\hline TOTAL & $25(67.9 \%)$ & $11(29.7 \%)$ & $1(2.7 \%)$ & $37(100 \%)$ \\
\hline
\end{tabular}

\section{Comment}

Table 3 shows that $35.1 \%$ of Millennials and $29.7 \%$ of Generation Xers who had served the company less than 10 years were disciplined for theft and other related offences.

Table 4. Cross tabulation on generational type and salary grade.

\begin{tabular}{cccccc}
\hline & \multicolumn{4}{c}{ Salary Grade } & \multirow{2}{*}{ TOTAL } \\
\cline { 2 - 5 } & SG5 & SG6 & SG7 & SG8 & \\
\hline Millennials (1981-1996) & $3(8.1 \%)$ & $9(24.3 \%)$ & $8(21.6 \%)$ & $1(2.7 \%)$ & $\mathbf{2 1 ( 5 6 . 8 \% )}$ \\
Generation Xers (1965-1980) & $0(0 \%)$ & $7(18.9 \%)$ & $7(18.9 \%)$ & $1(2.7 \%)$ & $\mathbf{1 5 ( 4 0 . 5 \% )}$ \\
Baby Boomers (1946-1964) & $0(0 \%)$ & $0(0 \%)$ & $1(2.7 \%)$ & $0(0 \%)$ & $\mathbf{1}(2.7 \%)$ \\
TOTAL & $\mathbf{3 ( 8 . 1 \% )}$ & $\mathbf{1 6 ( 4 3 . 2 \% )}$ & $\mathbf{1 6 ( 4 3 . 2 \% )}$ & $\mathbf{2 ( 5 . 4 \% )}$ & $\mathbf{3 7 ( 1 0 0 \% )}$ \\
\hline
\end{tabular}

\section{Comment}

Table 4 shows that $24.3 \%$ of M6 and $21.6 \%$ of M7 were Millennials and these 
were followed by $18.9 \%$ of M6 and $18.9 \%$ of M7 were Generation were disciplined for theft and other related offences.

Table 5. Cross tabulation on generational type and reasons for workplace theft incidents.

\begin{tabular}{|c|c|c|c|c|}
\hline \multirow[b]{2}{*}{ REASONS } & \multicolumn{3}{|c|}{ GENERATIONAL TYPE } & \multirow[b]{2}{*}{ TOTAL } \\
\hline & $\begin{array}{l}\text { Millennials } \\
(1981-1996)\end{array}$ & $\begin{array}{c}\text { Generation Xers } \\
(1965-1980)\end{array}$ & $\begin{array}{c}\text { Baby Boomers } \\
(1946-1964)\end{array}$ & \\
\hline $\begin{array}{l}\text { He wanted to be the company } \\
\text { witness }\end{array}$ & $1(2.7 \%)$ & 0 & 0 & $1(2.7 \%)$ \\
\hline Pressure from the co-accused & $5(13.5 \%)$ & $5(13.5 \%)$ & 0 & $10(10)$ \\
\hline For personal use & $1(2.7 \%)$ & $2(2.7 \%)$ & $1(2.7 \%)$ & $4(10.8 \%)$ \\
\hline For safe keeping in his Locker & $2(5.4 \%)$ & 0 & 0 & $2(2.7 \%)$ \\
\hline For usage at home & $1(2.7 \%)$ & 0 & 0 & $1(2.7 \%)$ \\
\hline $\begin{array}{l}\text { Need extra money due to } \\
\text { inadequate salary }\end{array}$ & $9(24.3 \%)$ & $4(10.8 \%)$ & 0 & $13(35.1 \%)$ \\
\hline Neglected his duties & 0 & $1(2.7 \%)$ & 0 & $1(2.7 \%)$ \\
\hline No idea on what happened to him & $1(2.7 \%)$ & 0 & 0 & $1(2.7 \%)$ \\
\hline $\begin{array}{l}\text { Overwhelming evidence against } \\
\text { accused which he denied. }\end{array}$ & 0 & $1(2.7 \%)$ & 0 & $1(2.7 \%)$ \\
\hline Thought that he was not seen & $1(2.7 \%)$ & 0 & 0 & $1(2.7 \%)$ \\
\hline Not part of the deal & 0 & $2(2.7 \%)$ & 0 & $2(2.7 \%)$ \\
\hline TOTAL & $21(56.8 \%)$ & $15(40.5 \%)$ & $1(2.7 \%)$ & $37(100 \%)$ \\
\hline
\end{tabular}

\section{Comment}

Table 5 shows that $24.3 \%$ of Millennials and $10.8 \%$ of Generation Xers engaged in theft activities because they needed extra money due to inadequate salaries. These were followed by $13.5 \%$ of Millennials and $13.5 \%$ of Generation Xers engaged in theft activities because pressure from the co-accused.

\section{Discussion}

The study reveals that Generational Type does influence employee Theft. The study found that the major reason why Millennials and Generational Type employees engage in theft incidents, is because of the need for extra money. In support of this finding, Krippel, 2008 [54] and Tewksbury et al. (2001) [42] state that lifestyles, pay and corporate wages (John et al., 2019) [10] create criminal opportunity. Therefore, whenever such employees report for work they look for items of value and unguarded, observe the pattern when it is unguarded and steal the item (Tewksbury et al., 2001) [42].

\section{Conclusion and Recommendation}

Based on the findings above, the study concludes that Generational Type and the lifestyle they lead to influence employee theft in workplace organizations. The 
evidence suggests that the need for extra money to meet social needs (lifestyle) is the main reason some employees engage in employee theft.

In conclusion, the researcher recommends that:

1) The employers should offer competitive salaries if employees are to meet their basic needs.

2) Management should redesign its induction and supervisory programmes to take into consideration the generational type and its effect on individual performance and prevent these individuals to refrain engaging in theft vices.

3) Security Department to intensify patrols or install more CCTV cameras to help provide real time data to prevent theft incidents from happening.

4) Management to carry out corresponding ideological education and training, so as to prevent employees from going astray.

5) Given the fact that the reports on which the study was based were drawn from one organization, the findings could not be generalized as such we recommend that a detailed study be conducted targeting multi-corporation organization with a large sample size to assess the impact national wide.

\section{Conflicts of Interest}

The author declares no conflicts of interest.

\section{References}

[1] Osborne, S. and Hammoud, M. (2017) Effective Employee Engagement in the Workplace. International Journal of Applied Management and Technology, 16, 50-67. https://doi.org/10.5590/IJAMT.2017.16.1.04

[2] Hill, S.A. and Birkinshaw, J. (2012) Ambidexterity and Survival in Corporate Venture Units. Journal of Management, 40, 1899-1931. https://doi.org/10.1177\%2F0149206312445925

[3] Musgrove, C., Ellinger, A.E. and Ellinger, A.D. (2014) Examining the Influence of Strategic Profit Emphases on Employee Engagement and Service Climate. Journal of Workplace Learning, 26, 152-171. https://doi.org/10.1108/JWL-08-2013-0057

[4] Adamson Mukhalipi, (2018) Employee Discipline Enhances Employee Engagement: An Affective Shift Model Perspective-A Literature Review. The International Journal of Management, 4, 59-69. https://doi.org/10.1177/0149206312445925

[5] Hausknecht, J.P. and Holwerda, J. A. (2013) When Does Employee Turnover Matter? Dynamicmember Configurations, Productive Capacity, and Collective Performance. Organization Science, 24, 210-225. https://doi.org/10.1287/orsc.1110.0720

[6] Bersin, J. (2014, March 15) Why Companies Fail to Engage Today's Workforce: The Overwhelmed Employee. Forbes.

https://www.forbes.com/sites/joshbersin/2014/03/15/why-companies-fail-to-engage -todays-workforce-the-overwhelmed-employee/\#34880e894726

[7] Conlow, R. (2017) Why Is Employee Engagement So Bad, So Often? Linkedin https://www.linkedin.com/pulse/why-employee-engagement-so-bad-often-rick-con low

[8] Robertson-Smith, G. and Markwick, C. (2009) Employee Engagement: A Review of Current Thinking. Institute for Employment Studies, Brighton.

[9] Clark Timothy, R. (2012) The Employee Engagement Mindset: The Six Drivers for 
Tapping into the Hidden Potential of Everyone in Your Company. McGraw Hill Companies, New York, 53-67.

[10] Ikurayeke, B.J., Konya, K.T. and Ejo-Orusa, H. (2019) Employee Dissatisfaction and Workplace Theft of Retail Firms in Port Harcourt, Nigeria. International Journal of Advanced Academic Research Social and Management Sciences, 5, 44-57.

[11] Eisner, S.P. (2005) Managing Generation Y. SAM Advanced Management Journal, 70, 4-15.

[12] Jurkiewicz, C.L. and Brown, R.G. (1998) GenXers vs Boomers vs Matures: Generational Comparisons of Public Employee Motivation. Review of Public Personnel Administration, 18, 18-37. https://doi.org/10.1177\%2F0734371X9801800403

[13] Kupperschmidt, B.R. (2000) Multi-Generation Employees: Strategies for Effective Management. The Health Care Manager, 19, 65-76. https://doi.org/10.1097/00126450-200019010-00011

[14] Macky, K., Gardner, D. and Forsyth, S. (2008) Generational Differences at Work: Introduction and Overview. Journal of Managerial Psychology, 23, 857-861. https://doi.org/10.1108/02683940810904358

[15] Adams, S.J. (2000) Generation X: How Understanding This Population Leads to Better Safety Programs. Professional Safety, 45, 26-29.

[16] Bradford, F.W. (1993) Understanding 'Gen X'. Marketing Research, 5, 54.

[17] Dittman, M. (2005) Generational Differences at Work. Monitor on Psychology, 36, 54-55. https://doi.org/10.1037/e408882005-034

[18] Fyock, C.D. (1990) America's Work Force Is Coming of Age. Lexington Books, Toronto.

[19] Jurkiewicz, C.E. (2000) Gen X and the Public Employee. Public Personnel Management, 29, 55-74. https://doi.org/10.1177\%2F009102600002900105

[20] Smola, K. and Sutton, C.D. (2002) Generational Differences: Revisiting Generational Work Values for the New Millennium. Journal of Organizational Behavior, 23, 363-382. https://doi.org/10.1002/job.147

[21] Westerman, J.W. and Yamamura, J.H. (2007) Generational Preferences for Work Environment fit: Effects on Employee Outcomes. Career Development International, 12, 150-161. https://doi.org/10.1108/13620430710733631

[22] Yu, H.C. and Miller, P. (2003) The Generation Gap and Cultural Influence-A Taiwan Empirical Investigation. Cross Cultural Management, 10, 23-41. https://doi.org/10.1108/13527600310797621

[23] Cennamo, L. and Gardner, D. (2008) Generational Differences in Work Values, Outcomes and Person-Organization Values Fit. Journal of Managerial Psychology, 23, 891-906. https://doi.org/10.1108/02683940810904385

[24] White, B. and Anexi, H.R. (2008) The Employee Engagement Equation in India. https://www.gpstrategies.com/solutions/organizational-performance/leadership-trai ning-programs/

[25] Byrne, Z.S. (2014) Understanding Employee Engagement: Theory, Research, and Practice. Psychology Press, New York.

[26] Deal, J., Altman, D. and Rogelberg, S. (2010) Millennials at Work: What We Know and What We Need to Do (If Anything). Journal of Business and Psychology, 25, 191-199. https://doi.org/10.1007/s10869-010-9177-2

[27] Wong, M., Gardiner, E., Lang, W. and Coulon, L. (2008) Generational Differences in Personality and Motivation: Do They Exist and What Are the Implications for 
the Workplace. Journal of Managerial Psychology, 23, 878-890. https://doi.org/10.1108/02683940810904376

[28] Dyer, W.G. (1995) Team Building: Current Issues and New Alternatives. 3rd Edition, Addison-Wesley, Reading.

[29] Zemke, R., Raines, C. and Filipczak, B. (2000) Generations at work: Managing the Clash of Veterans, Boomers, Xers and Nexters in Your Workplace. AMACOM Books, New York.

[30] Hung, K.H., Gu, F.F. and Yim, C.K. (2007) A Social Institutional Approach to Identifying Generational cohorts in China with a comparison with American consumers. Journal of International Business Studies, 38, 836-853. https://doi.org/10.1057/palgrave.jibs.8400288

[31] Mannheim, K. (1972) The Problem of Generations. In: Altbach, P.G. and Laufer, R.S., Eds., The New Pilgrims: Youth Protest in Transition, David McKay, New York, 101-138.

[32] Abramson, P.R. and Inglehart, R. (1995) Value Change in Global Perspective. University of Michigan Press, Ann Arbor. https://doi.org/10.3998/mpub.23627

[33] Inglehart, R. (1977) The Silent Revolution: Changing Values and Political Styles among Western Publics. Princeton University Press, Princeton.

[34] Inglehart, R. and Norris, P. (2003) Rising Ride: Gender Equality and Cultural Change around the World. Cambridge University Press, Cambridge.

https://doi.org/10.1017/CBO9780511550362

[35] Rogler, L.H. (2002) Historical Generations and Psychology: The Case of the Great Depression and World War II. American Psychologist, 57, 1013-1023.

https://doi.apa.org/doi/10.1037/0003-066X.57.12.1013

[36] McCrae, R.R. (2002) Cross-Cultural Research on the Five-Factor Model of Personality. Online Readings in Psychology and Culture, 4.

https://doi.org/10.9707/2307-0919.1038

[37] Deci, E.L. and Ryan, R.M. (1985) Intrinsic Motivation and Self-Determination in Human Behavior. Springer, Boston. https://doi.org/10.1007/978-1-4899-2271-7

[38] Blattner, J. and Walter, T.J. (2015) Creating and Sustaining a Highly Engaged Company Culture in a Multigenerational Workplace. Strategic HR Review, 14, 124-130. https://doi.org/10.1108/SHR-06-2015-0043

[39] Bowen, D.E. (2016) The Changing Role of Employees in Service Theory and Practice: An Interdisciplinary View. Human Resource Management Review, 26, 4-13. https://doi.org/10.1016/j.hrmr.2015.09.002

[40] Barrick, M.R., Thurgood, G.R., Smith, T.A. and Courtright, S.H. (2014) Collective Organizational Engagement: Linking Motivational Antecedents, Strategic Implementation, and Firm Performance. Academy of Management Journal, 58, 111-135. https://doi.org/10.5465/amj.2013.0227

[41] Mowbray, P.K., Wilkinson, A. and Tse, H.H.M. (2014) An Integrative Review of Employee Voice: Identifying a Common Conceptualization and Research Agenda. International Journal of Management Reviews, 17, 382-400. https://doi.org/10.1111/ijmr.12045

[42] Tewksbury, R. and Mustaine, E.E. (2001) Lifestyle Factors Associated with the Sexual Assault of Men: A Routine Activity Theory Analysis. Journal of Men's Studies, 9, 153-182. https://doi.org/10.3149\%2Fjms.0902.153

[43] Brantingham, P.J. and Brantingham, P.L. (1981) Environmental Criminology. Sage Publications, Beverly Hills. 
[44] Brantingham, P.L. and Brantingham, P.J. (1993) Nodes, paths and edges: Considerations on the complexity of crime and the physical environment. Journal of Environmental Psychology, 13, 3-28. https://doi.org/10.1016/S0272-4944(05)80212-9

[45] Clarke, R.V. and Cornish, D.B. (1985) Modeling Offenders' Decisions: A Framework for Research and Policy. Crime and Justice, 6, 147-185.

https://doi.org/10.1086/449106

[46] Astor, S.D. (1972) Twenty Steps to Preventing Theft in Business. Management Review, 61, 34-35.

[47] Lipman, M. (1978) Stealing: How America's Employees Are Stealing Their Companies' Blind. Harper's Magazine Press, New York.

[48] Kantor, S. (1983, July) How to Foil Employee Crime. Nation's Business, 38-39.

[49] Lydon, K. (1984, April) Employee Theft: A Costly Fringe Benefit. Security World, 27-31.

[50] Niehoff, B.P and Paul, R.J. (2000) Causes of Employee Theft and Strategies That HR Managers Can Use for Prevention. Human Resource Management, 39, 51-64. https://doi.org/10.1002/(SICI)1099-050X(200021)39:1\%3C51::AID-HRM5\%3E3.0.C $\underline{0 ; 2-5}$

[51] Kulas, J.T. Mcinnerney, J.E., Demuth, R. and Jawunski, V. (2007) Employee Satisfaction and Theft: Testing Climate Perceptions as a Mediator. Journal of Psychologys, 141, 389-402. https://doi.org/10.3200/JRLP.141.4.389-402

[52] Krishna Moorthy, M., Somasundaram, N.R., Arokiasamy, L., Nadarajah, G. and Marimuthu, M. (2011) Study on the Workplace Theft Behaviour of Employees in Supermarkets in Malaysia. International Journal of Academic Research, 3, 272-277.

[53] McClurg, L.A. and Butler, D.S. (2006) Workplace Theft: A Proposed Model and Research Agenda. Southern Business Review, 31, 25-34.

[54] Krippel, G.L. (2008) Employee Theft and the Coastal South Carolina Hospitality Industry: Incidence, Detection and Response. Tourism and Hospitality Research Journal, 8, 226-238. https://doi.org/10.1057\%2Fthr.2008.22

[55] MCM Records (2020) Kopala Reports for 2020: HR Admin Report. Disciplinary Report on Theft and other Related Offences. Unpublished. 